\title{
ARCHITECTURE OF Ambrosia psilostachya DC. INDIVIDUALS IN DIFFERENT HABITATS
}

\author{
Maciej Korczyński, Ewa Krasicka-Korczyńska \\ Department of Botany and Ecology, Faculty of Agriculture and Biotechnology, University of Technology and Life Sciences \\ Al. S. Kaliskiego 7, PL-85-796 Bydgoszcz, Poland, \\ e-mail: malerudy@wp.pl
}

Received: 03.03.2011

\begin{abstract}
Ambrosia psilostachya is a plant of North American origin, well-domesticated in Poland. It covers ruderal habitats and is found in crops and in city green areas. The density of ragweed shoots in the researched areas ranged from 55 to 111 per $\mathrm{m}^{2}$. The production of biomass of this species relates to the production of synanthropic communities and city lawns. The factor limiting the population is cutting which affects mostly the number of shoots per patch, less considerably the state of a single individual. Habitats affected by mechanical factors are the biggest source of pollen causing allergies.
\end{abstract}

Key words: Ambrosia psilostachya, biomass, morphology, dispersion, male inflorescence, Bydgoszcz

\section{INTRODUCTION}

Species of the genus Ambrosia represent a group of alien plants occurring in the flora of Poland. They have the status of ephemerophytes or kenophytes (R u t k o w s k i , 2004). It is of special importance that their pollen present in the air of many regions has allergic properties (Chło pek and Tokarska-Guz i k, 2006; S t a c h, 2006). Western ragweed Ambrosia psilostachya DC. is a perennial of North American origin, widely, secondarily dispersed both in Europe and in Asia (B a s s e t and Crom pto n, 1975; La aidi and Laaidi, 1999; Tseng and Peng, 2004, M a kra et al. 2005). In Poland it appears in a dozen or so regions far from one another $(\mathrm{Z} \mathrm{a} \mathrm{j} \mathrm{ą} \mathrm{c}$ and $\mathrm{Z}$ a j ą c , 2001). It is dispersed throughout the country and the pollen of this plant is noted in the air of many cities. It comes from local sources and is transported from far away (M i s i e w i c z, 1976; S tę p a l s k a et al. 2002; P u c, 2006; S m it h et al. 2008).
Ambrosia psilostachya was found for the first time in Bydgoszcz in 1989. At that time, it was considered to be a quarantine plant. The observations of this species suggest that under the conditions of our country it propagates and disperses vegetatively. Despite abundant pollination, neither fully developed nor sprouting fruits were found (Krasicka-Korczyńska and Korczyńs ki, 1994; Korczy ński and Krasicka-Korczyńska, 2011). So far, over 70 plant patches with ragweed have been recorded in Bydgoszcz. It occurs mainly in ruderal communities but also in flower beds, lawns and in agricultural crops.

Climate warming and a positive reaction of ragweed to this process can enhance its spread (Wan et al. 2002). This plant has big recuperative powers of roots (Miziniak and Pracyk, 2002; Miziniak, 2005). Due to allergic properties of hairs on the shoot and pollen as well as its competitiveness towards crops, this invasive species will generate economic and social problems (T a c i k, 1971). The current state of knowledge on Ambrosia psilostachya dispersion in Poland does not make it possible to provide the final definition of the degree of its harmfulness towards crops and human health (Opinion of ... 2007).

The aim of the present research was to determine the variation in selected morphological features and the structure of biomass states in ragweed individuals as well as shoot density in varied habitats (ruderal, roadside, and lawn).

\section{MATERIAL AND METHODS}

The analyses involved rooted aboveground $\mathrm{Am}$ brosia psylostachya shoots which were considered as individuals of that species. The following features were 
determined: plant height (by measuring the longest shoot because it is a measure of plant size after cutting the erect stem), length of male shoot inflorescences as well as the total biomass of leaves, stems, and male shoot inflorescences. The material for analysis was made up of 30 individuals, sampled in mid-September 2005 from 5 localities (Table 1). The localities researched in 2005 represent three types of habitats and communities: ruderal (patches 2,3), roadside (patches 11, 12), and lawn (patch 5) habitats from the area of the city of Bydgoszcz. The air-dry biomass was weighed with an accuracy of up to $0.01 \mathrm{~g}$. The significance of the differences was verified with one-way analysis of the variance and by determining least significant differences (R u s z c z y c, 1978).

The observations of ragweed shoot density and their dispersion pattern in the above-mentioned habitat and community types were continued over the period 2005-2007 based on the results for 64 adjacent basic plots $0.25 \times 0.25 \mathrm{~m}$ in size in each patch (K e r s h a w, 1978). The analyses were carried out in three ragweed habitats: ruderal (patches 1, 2, 3, 4), lawn (patches 5, $6,7,8$ ), and roadside (patches $9,10,11,12$ ) (Fig. 1). Because of the discrete character of the plant density variable, harmonic means were given as well as their standard error and standard deviation (Fig. 2). Due to random causes, seven areas were the only ones in which a three-year measurement cycle was performed (Fig. 3).

There was also determined the productivity of the aboveground part of ragweed per $1 \mathrm{~m}^{2}$ of the patch of the plant community developing in respective habitats and total length of all male inflorescences per $1 \mathrm{~m}^{2}$. They were calculated as a product of individual plant weight or length of male inflorescences and their density (Fig. 4). These features were recognised as the measures of risk of perennial ragweed pollen from the respective habitats.

Table 1.

Features of Ambrosia psilostachya individuals in 2005

\begin{tabular}{|c|c|c|c|c|c|c|c|c|c|}
\hline Locality & & & $\begin{array}{l}\text { Maximum } \\
\text { shoot height } \\
(\mathrm{cm})\end{array}$ & $\begin{array}{l}\text { Number of male } \\
\text { inflorescence shoots } \\
\text { (pieces) }\end{array}$ & $\begin{array}{l}\text { Length of male in- } \\
\text { florescence shoots } \\
\text { on the plant }(\mathrm{cm})\end{array}$ & $\begin{array}{l}\text { Leaf } \\
\text { biomass } \\
\quad(g)\end{array}$ & $\begin{array}{c}\text { Stem } \\
\text { biomass } \\
(\mathrm{g})\end{array}$ & $\begin{array}{c}\text { Male inflores- } \\
\text { cence shoot } \\
\text { biomass }(\mathrm{g})\end{array}$ & $\begin{array}{c}\text { Total } \\
\text { biomass } \\
\text { (g) }\end{array}$ \\
\hline \multirow{2}{*}{ lawn } & \multirow{2}{*}{ (5) } & $\mathrm{x}$ & 30.94 & 4.1 & 14.10 & 1.61 & 0.99 & 0.12 & 2.71 \\
\hline & & $V \%$ & 17.9 & 142.5 & 181.0 & 61.2 & 70.1 & 176.5 & 67.8 \\
\hline \multirow{2}{*}{ ruderal } & \multirow{2}{*}{ (2) } & $\mathrm{x}$ & 37.65 & 2.8 & 9.69 & 0.56 & 0.64 & 0.08 & 1.28 \\
\hline & & $V \%$ & 8.7 & 63.5 & 39.6 & 35.4 & 36.7 & 54.48 & 35.7 \\
\hline \multirow{2}{*}{ ruderal } & \multirow{2}{*}{ (3) } & $\mathrm{x}$ & 20.55 & 1.0 & 4.52 & 0.15 & 0.18 & 0.04 & 0.37 \\
\hline & & $V \%$ & 8.4 & 17.7 & 32.8 & 49.1 & 39.7 & 182.2 & 39.4 \\
\hline \multirow{2}{*}{ roadside } & \multirow{2}{*}{$(12)$} & $\mathrm{x}$ & 68.05 & 12.7 & 75.35 & 1.70 & 2.92 & 0.56 & 5.18 \\
\hline & & $V \%$ & 9.4 & 90.3 & 92.6 & 78.0 & 66.4 & 103.6 & 73.2 \\
\hline \multirow{2}{*}{ roadside } & \multirow{2}{*}{ (11) } & $\mathrm{x}$ & 45.63 & 3.7 & 9.65 & 1.00 & 0.83 & 0.09 & 1.92 \\
\hline & & $V \%$ & 20.6 & 98.0 & 99.7 & 60.3 & 62.4 & 106.2 & 60.3 \\
\hline \multicolumn{3}{|c|}{$\mathrm{NIR}_{0.05} \mathrm{LSD}_{0.05}$} & 3,01 & 3.90 & 17.10 & 0.40 & 0.49 & 0.14 & 1.00 \\
\hline
\end{tabular}

(2), (3), (5), (11), (12) - plant patch numbers

Table 2.

Changes in Ambrosia psilostachya shoot density in particular habitats (V - coefficient of variation)

\begin{tabular}{lrrrrrrr}
\hline Year & 2005 & & 2006 & & \multicolumn{2}{c}{2007} & \multicolumn{2}{c}{$\begin{array}{c}\text { Weighted mean } \\
2005-2007\end{array}$} \\
\hline Habitat & shoots $\times \mathrm{m}^{-2}$ & $\mathrm{~V} \%$ & shoots $\times \mathrm{m}^{-2}$ & $\mathrm{~V} \%$ & shoots $\times \mathrm{m}^{-2}$ & $\mathrm{~V} \%$ & shoots $\times \mathrm{m}^{-2}$ \\
\hline ruderal & 95.1 & 29.9 & 68.2 & 53.4 & 78.8 & 57.0 & 81.1 \\
lawns & 55.1 & 74.9 & 67.9 & 39.1 & 82.0 & 5.1 & 65.3 \\
roadsides & 108.0 & 52.2 & 76.4 & 15.1 & 111.3 & 4.9 & 100.9 \\
\hline Weighted mean & 86.1 & 53.3 & 69.9 & 37.9 & 90.7 & 28.6 & \\
\hline
\end{tabular}




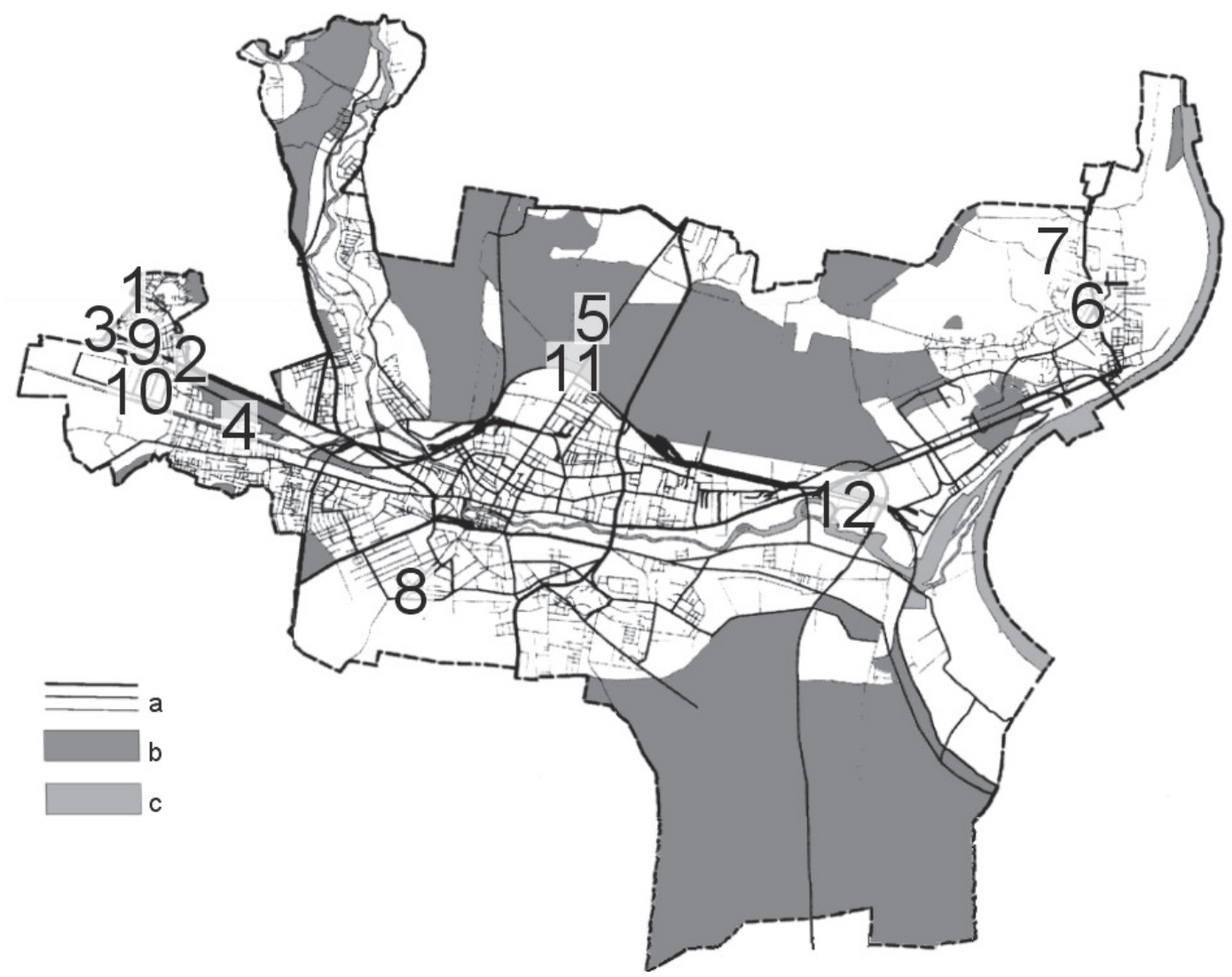

Fig. 1. Distribution of the studied plant patches (1-12) with Ambrosia psilostachya in Bydgoszcz ( $\mathrm{a}-$ developed areas, $\mathrm{b}-$ forests, $\mathrm{c}$ - rivers and canals).

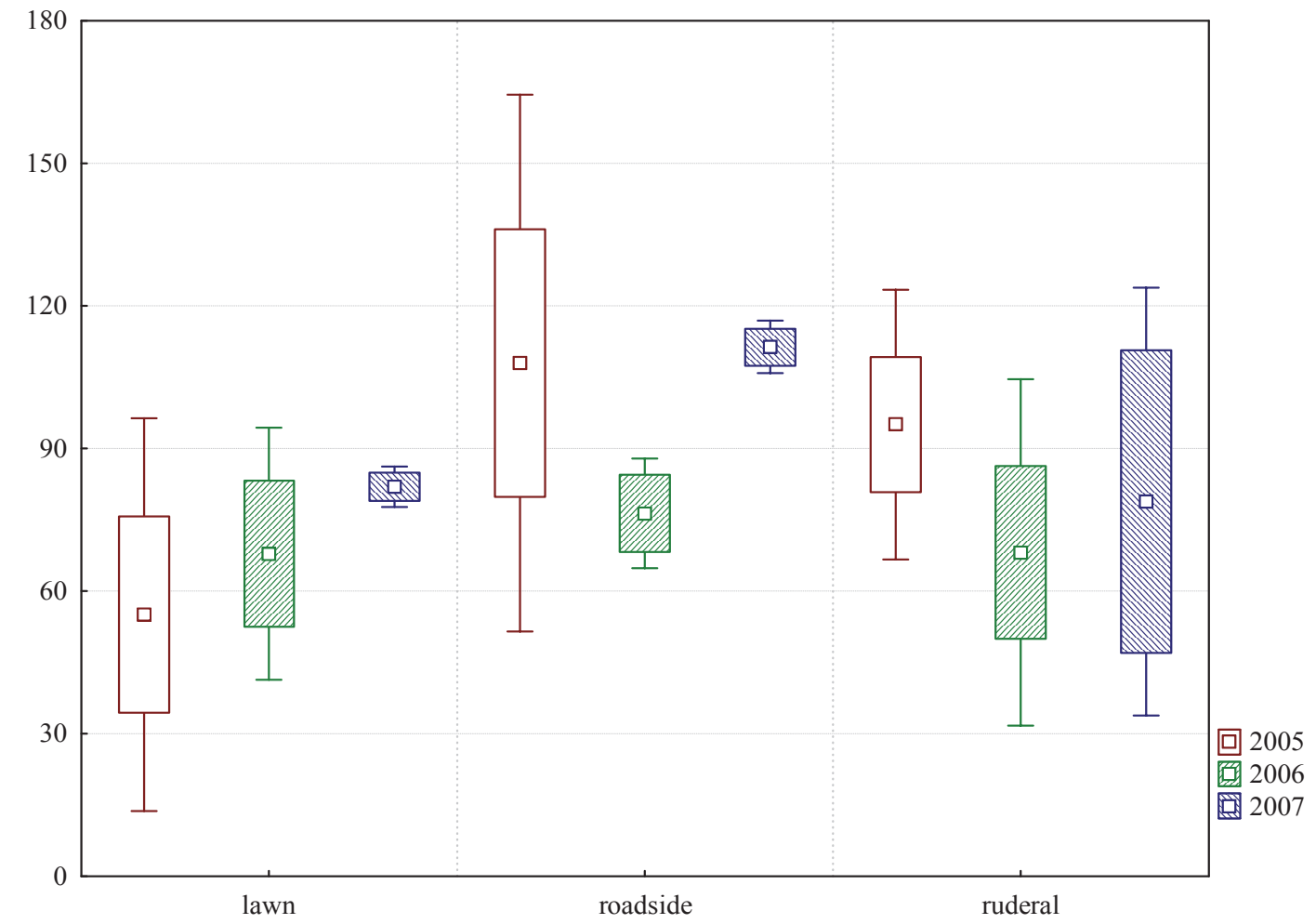

Fig. 2. Comparison of the density of Ambrosia psilostachya individuals (piece $\times \mathrm{m}^{-2}$ ) in three habitats in years 2005-2007. Box: mean \pm standard error; whiskers: mean \pm standard deviation. 
A $\longrightarrow-1--2 \longrightarrow-2-3 \cdot-x-\cdot 4$

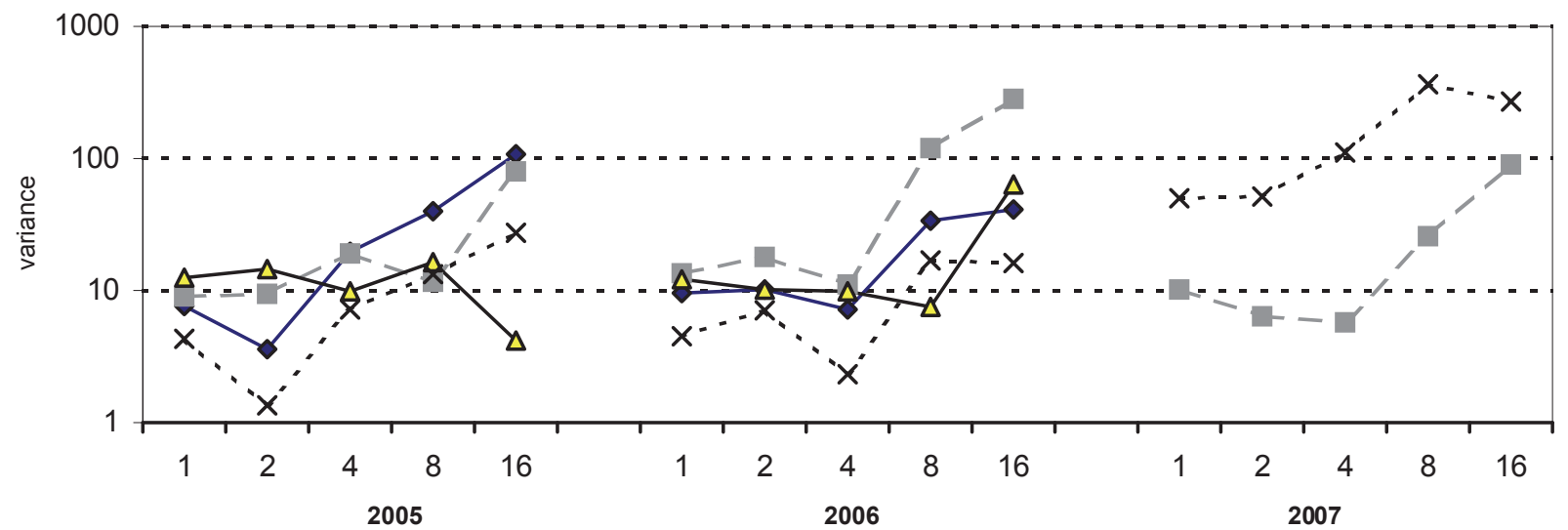

$\mathrm{B}$
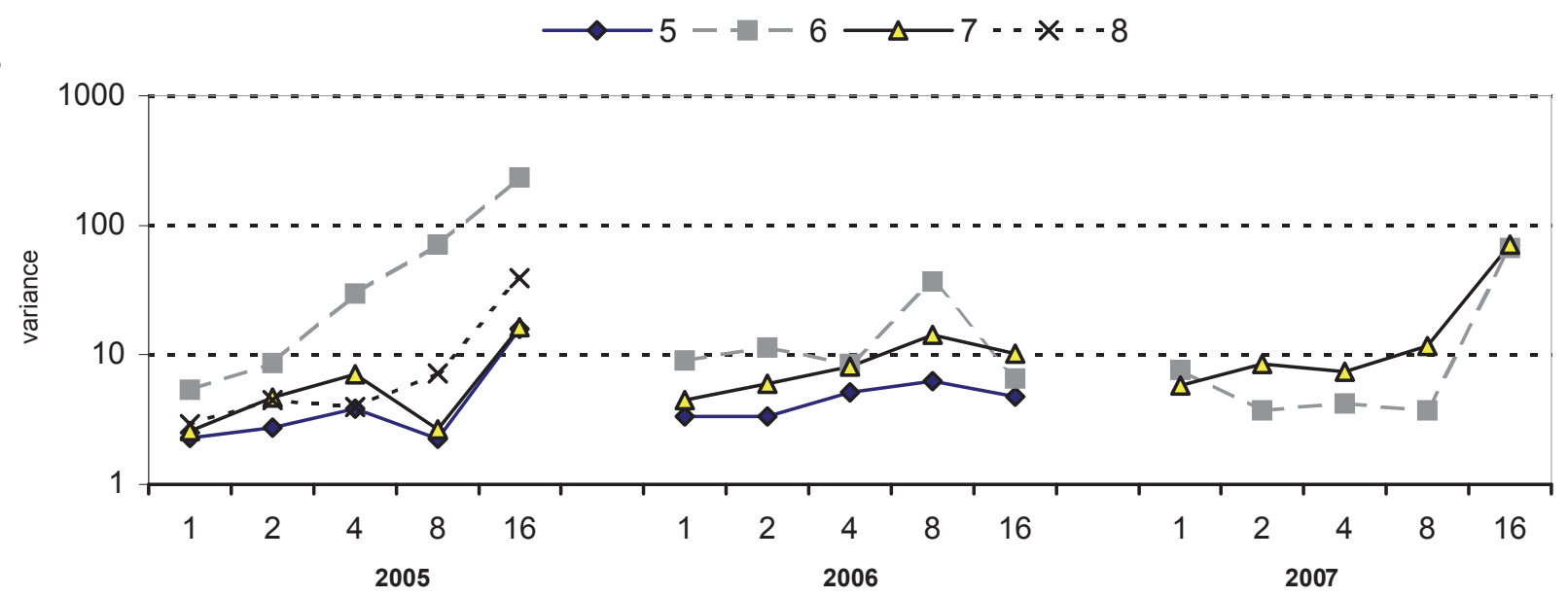

$\mathrm{C}$
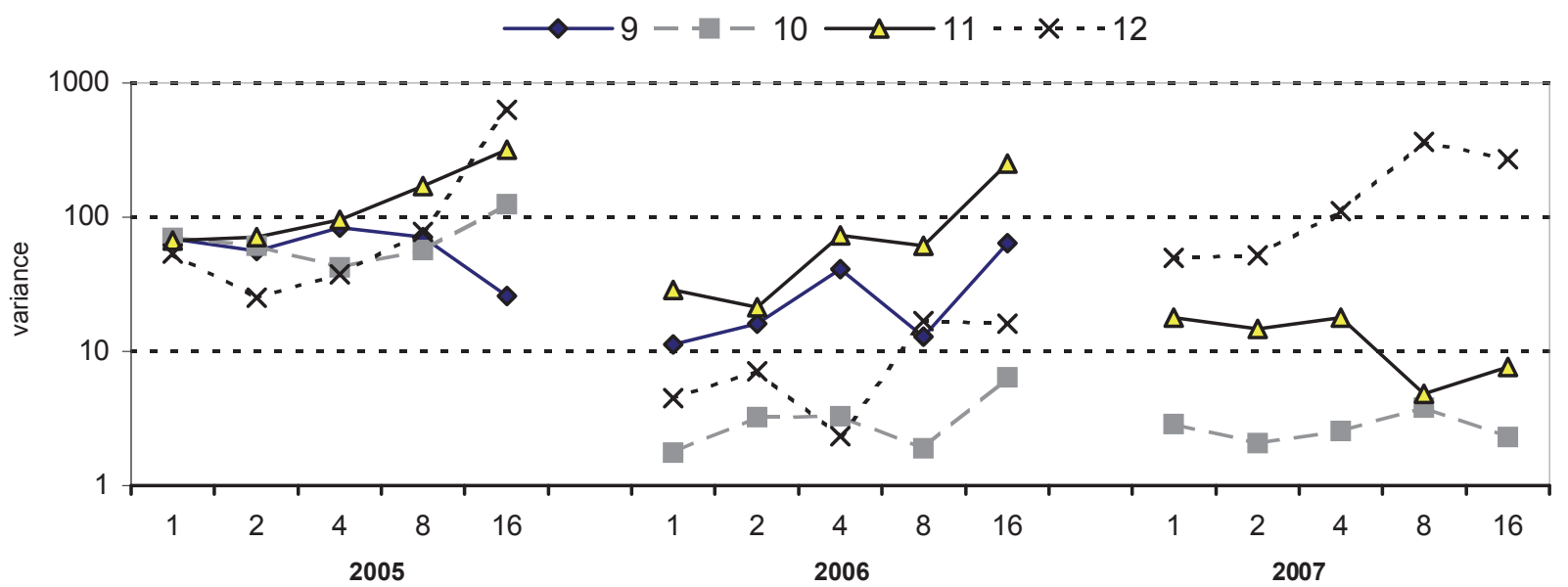

Fig. 3. Distribution patterns for Ambrosia psilostachya individuals in the habitats studied in 2005-2007: ruderal (A); lawns (B); roadsides (C); 1-12 plant patch numbers. Plot dimension: 1) $0.25 \times 0.25 \mathrm{~m}$; 2) $0.25 \times 0.50 \mathrm{~m}$; 4) $0.5 \times 0.5 \mathrm{~m}$; 8) $-0.5 \times 1.0 \mathrm{~m}$; 16) $1.0 \times 2.0 \mathrm{~m}$. 


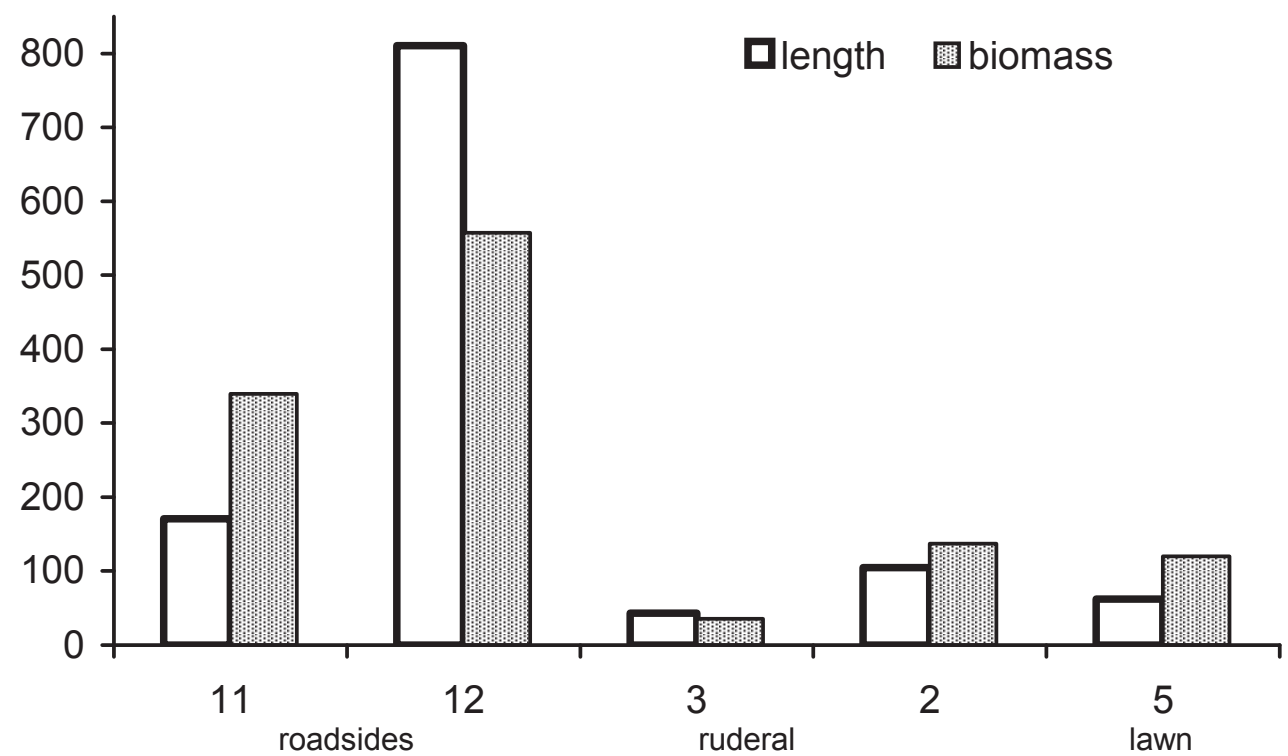

Fig. 4. Western ragweed total biomass productivity $\left(\mathrm{g} \times \mathrm{m}^{-2}\right)$ and length of all male inflorescence shoots $\left(\mathrm{dm} \times \mathrm{m}^{-2}\right)$, in 2005.

\section{RESULTS}

\section{Morphological features}

Amongst the studied habitats, the highest plants were found in phytocoenoses slightly damaged by vehicles on roadsides or exposed to the pressure from winter road clearing agents; such conditions eliminate less resistant individuals. As a result of lawn-mowing, the plants on lawns assumed the creeping habit, which did not have a clear effect on their size (Table 1). The length of all inflorescence shoots on the plant ranged from nearly $4.5 \mathrm{~cm}$ in ruderal habitats to over $75 \mathrm{~cm}$ in roadside habitats. Lawn-mowing under urban green areas conditions was not a factor limiting the size of male inflorescences. Extremely abundant flowering was reported in the roadside plant patch (12) in the complex of railway areas. The total length of male inflorescences reached $75 \mathrm{~cm}$ there. The length of inflorescences was the feature which was differentiated by the highest values of the coefficient of variation (V) (Table 1). Plants under greater mechanical pressure had more numerous and longer male shoot inflorescences. The morphological feature most strongly diversifying the investigated patches and habitats was plant height - the smallest difference amounts to 6.71, at $\operatorname{LSD}_{0.05}=3,01$.

\section{Density}

For the three successive years, the density of Ambrosia psilostachya individuals was recorded in the same plant patches. Its mean values noted in the successive years ranged from 55 on the lawn to 111 shoots per sq. meter on the roadsides (Table 2). The highest density in one of the study areas reached 186 shoots (roadside). The range between the averages for years and habitats is similar and does not exceed 20.

Constant lawn-mowing limits the coverage of the habitat by ragweed plants reducing their density by about $30 \%$ compared with habitats which were left unmowed throughout the three years of observations. Average density both in individual habitats and years was characterized by high variation. The obtained average values are within the range of the mean \pm standard error of the results for ruderal patches in 2007 (Fig. 2).

In the spatial distribution of ragweed, there is a trend towards the development of varied distribution patterns in the respective years and habitats (Fig. 3); however, we recorded a trend to form clusters with an area exceeding $0.5 \mathrm{~m}^{2}$.

\section{Biomass}

The highest biomass of a single plant was recorded in one plant in one patch (12) on the roadside (Table 1) where the plants were also the highest. Under the conditions of ruderal habitats, without a drastic anthropogenic effect, the weight of individuals ranged from 0.37 to $1.28 \mathrm{~g}$ and, as compared with the other habitats, it was lowest. A high variation was found in the ratio of leaf weight to stem weight, although one should also factor in a varied rate of dying of assimilation apparatus in the respective habitats. The reproduction effort, defined as the ratio of male inflorescence weight to stem weight, ranged from 11 to $22 \%$. This feature does not differentiate the lawn habitat from the other ones, either. 


\section{DISCUSSION}

Ragweed shoots in the plant patches studied represented the entire size range known ( $\mathrm{R} \mathrm{u}$ t k o w s k i, 2004). Under the conditions of roadside habitats, plant height exceeded the values recorded in a pot experiment where no significant limiting factors were present (Krasicka-Korczyńska and Korczyński, 1994). In all the analysed habitats, ragweed reached a higher height than in experiments on the regeneration of this plant (Miziniak and Praczyk, 2002). Plant biomass in vase fertilization experiments $(\mathrm{M} \mathrm{i} \mathrm{-}$ $\mathrm{ziniak}, 2005)$ was comparable to the results in the investigated habitats.

The biomass of a single individual observed in most patches was higher than that reported by $\mathrm{W}$ a $\mathrm{n}$ et al. (2002) when exposed to competition with group $\mathrm{C}_{4}$ grasses. It was comparable only with that reported in ruderal habitats. Individuals of $A$. psilostachya in lawns and roadside habitats had more biomass relative to conspecifics in tallgrass prairie ( $\mathrm{F} \mathrm{a} \mathrm{h} \mathrm{n} \mathrm{e} \mathrm{s} \mathrm{t} \mathrm{o} \mathrm{c} \mathrm{k}$ and $\mathrm{Kn}$ a p p 1994). Moderate cutting turned out to be a less limiting factor than grazing. This confirms the thesis about better growth conditions for alien species outside the conditions of their natural co-evolution (G n i a z d ow s ka, 2005).

The habitats available to ragweed exposed to free competition seem less open and do not allow for using its potential. The potential of this plant, as measured by shoot weight that can be produced, is a few-fold higher. Its reproductive effort fell within the range reported in earlier research (K r a s i c ka - K o r c z y ń ska and Korczyński, 1994). The total length of male inflorescence stems in the plant patches reached up to $81 \mathrm{~m}$ per $1 \mathrm{~m}^{2}$ in the roadside habitat. From the phytosanitary point of view, this value is important because ragweed pollen is the hardest allergen to avoid.

The maximum shoot density slightly exceeds that reported under prairie conditions ( $\mathrm{W}$ a $\mathrm{n}$ et al. 2002). A varied distribution pattern of individuals can result from the dynamics of the process of habitat colonization by new specimens derived from radicle buds. This property of the population is also referred to by Czarnecka (1995). Salzman (1985) found in Ambrosia psilostachya changes in distribution of ramets corresponding to the soil environment dynamics. The size of the acreage exceeding $0.5 \mathrm{~m}^{2}$ is connected with the length of single roots, at the ends of which wintering buds set, making it possible for the plants to overwinter (K r a s i c k a - K o r c z y ń s ka and Kor c z y ńs k i , 1994).

The production of biomass of aboveground ragweed shoots (Fig. 3) during the vegetation period related to the production of cultivated city lawns and synanthropic communities in the city (Korc z y ń s ki ,
1987; Wysocki, 1994). A sporadic removal of some shoots does not have a clear effect on limiting the population productiveness ( $\mathrm{W}$ an et al. 2002). A relatively high weight of the single individual balances the lower density on city lawns.

\section{CONCLUSIONS}

The structure of a single Ambrosia psilostachya individual and the spatial distribution is strongly modified by habitat conditions. The factor limiting its density is cutting; however, with a low intensity of this treatment, the coverage of a habitat by ragweed can be balanced by a good condition of a single individual. The ragweed biomass in the study area is higher than in its native habitats and points to a more effective use of habitat resources by this alien species in its geographic region. Roadsides pose the greatest risk to persons allergic to the pollen of western ragweed. Plants reach the highest productivity there and they set the longest male inflorescences.

\section{Acknowledgments}

The authors want to thank Prof. Dr Ewa Jendrzejczak for her assistance in statistical procedures.

\section{REFERENCES}

Basset I.J., Crompton C.W., 1975. The biology of Canadian weeds. 11. Ambrosia artemisiifolia L. and A. psilostachya DC. Can. J. Plant Sci. 55: 463-476.

Chłopek K., Tokarska-Guzik B., 2006. Pyłek ambrozji (Ambrosia) w aeroplanktonie Górnego Śląska. / Ragweed (Ambrosia) pollen in aeroplankton of Upper Silesia. Acta Agrobot. 59 (1): 335-345. (in Polish)

Czarnecka B ., 1995. Biologia i ekologia izolowanych populacji Senecio rivularis (Waldst. et Kit.) DC. i Senecio umbrosus Waldst. et Kit. / Biology and Ecology of Isolated Populations of Senecio rivularis (Waldst. et Kit.) DC. and Senecio umbrosus Waldst. et Kit. Wydawnictwo Uniwersytetu Marii Curie-Skłodowskiej, Lublin, 263. (in Polish)

Fahnestock J.T., Knapp A.K., 1994. Plant responses to selective grazing by bison: interactions between light, herbivory and water stress. Vegetatio, 115: 123-131.

Gniazdowka A., 2005. Oddziaływania allelopatyczne „,nowa broń” roślin inwazyjnych. / Allelopathic effects - a "new weapon" of invasive plants. Kosmos, 54 (2-3): 221-226. (in Polish)

Kershaw K. A., 1978. Ilościowa i dynamiczna ekologia roślin. Państwowe Wydawnictwo Naukowe, Warszawa, 382 (in Polish).

Korczyński M., 1987. Zróżnicowanie zbiorowisk trawiastych ekosystemu miejskiego w Bydgoszczy. Maszynopis. Katedra Botaniki i Ekologii, Akademia Techniczno-Rolnicza, Bydgoszcz, 101 (in Polish). 
Korczyński M., Krasicka-Korczyńska E., 2011 Rozprzestrzenianie się Ambrosia psilostachya DC. na terenie miasta Bydgoszczy. IAmbrosia psilostachya DC. spreading in Bydgoszcz town area. Ekologia i Technika XIX, 3A: 182-186.

Krasicka-Korczyńska E., Korczyński M., 1994. Ambrosia psilostachya DC. - rozprzestrzeniający się gatunek kwarantannowy. [In:] XVII Krajowa Konferencja „Przyczyny i źródła zachwaszczenia pól uprawnych". Wydawnictwo ART, Olsztyn-Bęsia: 141-148. (in Polish)

Laaidi K., Laaidi M., 1999. Airborne pollen of Ambrosia in Burgundy (France) 1996-1997. Aerobiologia, 15: 65-69.

Makra L., Juhász M., Béczi R., Borsos E., 2005. The history and impacts of airborne Ambrosia (Asteraceae) pollen in Hungary. Grana, 44: 57-64.

Misiewicz J., 1976. Flora synantropijna i zbiorowiska ruderalne polskich portów morskich. Wyższa Szkoła Pedagogiczna, Słupsk, 321. (in Polish)

Mizin i a k W., 2005. Wpływ nawożenia makroskładnikami NPK na wzrost i rozwój ambrozji zachodniej (Ambrosia psilostachya D.C.). / The effect of NPK fertilization on the growth and development of Ambrosia psilostachya D.C. Prog. Plant Protection/Post. Ochr. Roślin, 42 (2): 922-925. (in Polish)

Miziniak W., Praczyk T., 2002. Regeneracja roślin ambrozji zachodniej (Ambrosia psilostachya D.C.) w korzeni na różnych typach gleb. / Regeneration of Ambrosia psilostachya D.C. plants from roots in different soil types. Prog. Plant Protection/Post. Ochr. Roślin, 41 (2): 547-550. (in Polish)

Opinion of the Scientific Panel on Plant Health on a request from the Commission on the pest risk assessment made by Poland on Ambrosia spp. 2007. The EFSA Journal, 528: 1-32.

Puc M., 2006. Ragweed and mugwort pollen in Szczecin, Poland. Aerobiologia, 22: 67-78.

Rut kow sk i L., 2004. Klucz do oznaczania roślin naczyniowych Polski niżowej. Wydawnictwo Naukowe PWN, Warszawa, 814. (in Polish)

Ruszczyc Z ., 1978. Metodyka doświadczeń zootechnicznych. Państwowe Wydawnictwo Rolnicze i Leśne, Warszawa, 425. (in Polish)

Salzman A.T., 1985. Habitat selection in clone plant. Science, 228: 603-604.

Smith M., Skjřth C.A., Myszkowska D., Uruska A., Puc M., Stach A., Balwierz Z., Chłopek K., Piotrowska K., Kasprzyk I., Brandt J., 2008. Long-range transport of Ambrosia pollen to Poland. Agric. For. Meteorol., 148 (10): 14021411 .
Stach A., 2006. Is pollen of ragweed (Ambrosia L.) a threat to people with allergies in the Wielkopolska region? Biodiv. Res. Conserv. 3-4: 320-323.

Stępalska D., Szczepanek K., Myszkowska D., 2002. Variation in Ambrosia pollen concentration in Southern and Central Poland in 1982-1999. Aerobiologia, 18: 13-22,

Tacik T., 1971. Ambrosia L., Ambrozja. [In:] Flora Polska. Rośliny naczyniowe Polski i ziem ościennych, (ed.) B. Pawłowski, A. Jasiewicz. Volume XII: 222-225. Państwowe Wydawnictwo Naukowe, Warszawa-Kraków. (in Polish)

Tseng Y-H., Peng Ch., 2004. Ambrosia psilostachya DC. (Asteraceae) a Newly Naturalized Plant in Taiwan. Teyou Shengwu Yanjiu, 6 (1): 71-74.

Wan S., Yuan T., Bowdish S., Wallace L., Russel S.D., Luo Y., 2002. Response of an allergenic species, Ambrosia psilostachya (Asteraceae), to experimental warming and clipping: implication for human health. Am. J. Bot. 89 (11): 1843-1846.

Wysocki Cz., 1994. Studia nad funkcjonowaniem trawników na obszarach zurbanizowanych. Wydawnictwo SGGW, Warszawa, 95. (in Polish)

$\mathrm{Zaj}$ ąc, Zając M., (eds) 2001. Atlas rozmieszczenia roślin naczyniowych w Polsce. Instytut Botaniki Uniwersytetu Jagiellońskiego, Kraków, 714. (in Polish)

\section{Architektura osobników Ambrosia psilostachya DC. w różnych warunkach siedliskowych}

\section{Streszczenie}

Ambrosia psilostachya jest rośliną pochodzenia północnoamerykańskiego trwale zadomowioną w Polsce. Zajmuje siedliska ruderalne, spotykana jest w uprawach i terenach zieleni miejskiej. Zagęszczenie pędów ambrozji na badanych powierzchniach wahało się od 55 do $111 \mathrm{na}^{2}$. Produkcja biomasy tego gatunku nawiązuje do produkcji zbiorowisk synantropijnych i kultywowanych trawników miejskich. Poza obszarem naturalnego występowania ambrozja rośnie w nieco większym zagęszczeniu i jej osobniki osiągają większą biomasę. Koszenie nie jest czynnikiem eliminującym okazy ze zbiorowisk roślinnych. Ogranicza liczbę pędów w płacie, w mniejszym stopniu wpływa na stan pojedynczego osobnika. Największym źródłem wywołującego alergie pyłku ambrozji są siedliska poddawane oddziaływaniom mechanicznym. 
